\title{
The new Other Catalans at school: decreasing unevenness but increasing isolation
}

Reviewed version published in Valiente, Oscar and Rambla, Xavier(2009)'The new Other Catalans at school: decreasing unevenness but increasing isolation',International Studies in Sociology of Education, 19:2,105 - 117

Authors:

Oscar Valiente and Xavier Rambla

Department of Sociology

Universitat Autònoma de Barcelona

Campus de Bellaterra- Edifici B

08193- Cerdanyola del Vallès (Barcelona: Spain)

Telephone: 93/581.42.12 and 93/581.40.93

e-mail: oscar.valiente@uab.cat and xavier.rambla@uab.cat

\section{KEYWORDS}

School segregation. Social Inequalities. Intersectional approach. Education policy.

\section{SPONSORSHIP:}

This article is a product of Project EDU2008-00186, funded by the Ministry of Science (Spain), which aims to explore the contradictory implementation of Education for All in several countries. A first version was presented and discussed at the International Conference in Sociology of Education (Institute of Education, University of London, in January 2008). We thank all the comments of the participants in that event and the two anonymous reviewers.

\section{OSCAR VALIENTE}

Oscar Valiente holds a degree in Sociology. He is a research assistant working at the Department of Sociology (UAB) and the Seminar for the Analysis of Social Policy (selene.uab.es/dep-sociologia/saps_cat.html) as well as the Interdisciplinary Group on Education Policy (http://www.ub.edu/gipe). He holds a Pre-doctoral Scholarship between 2005 and 2009.

\section{XAVIER RAMBLA}

Xavier Rambla holds degrees in History and Sociology and a $\mathrm{PhD}$ in Sociology from Autonomous University of Barcelona (UAB). He has been a lecturer at University of Vic (1995-2001) and a researcher at the Critical Coeducation Program of the UAB Institute of Education (1994-2000). Since 2001 he is Associate Professor of Sociology at the Autonomous University of Barcelona. Currently, he is the co-ordinator of the Seminar for the Analysis of Social Policy (selene.uab.es/dep-sociologia/saps_cat.html) as well as a researcher of the Interdisciplinary Group on Education Policy (http://www.ub.edu/gipe). 
The 2006 Statute of Autonomy defines Catalonia as a national autonomous community located within Spain. So far, this is the most recent outcome of a nation-building process that started one century ago with the emergence of mass politics. Nationalism has intermingled with immigration and ethnic relations during these long-term changes, inasmuch as the 'Catalan nation' had to integrate immigrants from Southern Spain during the 1920s and the 1950-70s. At this second moment the governing dictatorship hindered integration by not recognising the language at school and repressing the public manifestation of the Catalan identity. However, the social status of the Catalan language remained high (Woolard, 1989), and politically engaged middle-classes sent their children to private schools that taught it in a semi-clandestine way ${ }^{1}$.

In this second period the journalist Francesc Candel (1964) wrote a long report on the social conditions of immigrants, where he argued that previous definitions of the national identity, focused on historical continuity and Catholic religion, should be revised in order to integrate the incoming 'Other Catalans'. In his view, democratic movements should not only resist the contemporary authoritarian, anti-Catalan oppression, but also struggle to build a welfare state and to broaden the boundaries of the Catalan identity. Almost forty years later, Candel and Cuenca (2001) wrote again about the new Other Catalans, who had arrived again mostly from Third World countries, and posited new questions about rights, identities and politics. Coherently, they reported on people's everyday material and social conditions, which should be the grounds of any successful new inclusive project and the associated public policies.

\footnotetext{
1 Since the 1960s some private schools were created so as to promote Catalan-based teaching, pedagogic innovation inspired on child-centred approaches, democracy and the Catalan nation. During the political transition they constituted the School Group for Catalan Public Education (Col-lectiu d'Escoles per a l'Escola Pública Catalana), who asked for inclusion into the state-run sector managed by the new Catalan Government (Generalitat de Catalunya). They were finally integrated into this sector between 1983 and 1988
} 
Our article analyses the social segregation of the new Other Catalans in the school system. Altogether with citizenship status, the labour market, housing and language policy, this is one of the current, burning debates in Catalan politics. Actually, in 2001 they were $3 \%$ of the schooling population, and this figure had climbed to $12 \%$ in $2006^{2}$.

The first two sections conceptualize the topic from the perspective of intersectional analysis. The third one outlines the Catalan Continental regime of schooling. The next section introduces the main indices of school social segregation and reports the main findings: namely, unevenness decreases, isolation escalates and two distinct local patterns are identified. Then, we reflect on the theoretical, intersectional implications of this empirical result.

\section{Unitary and multiple approaches to the integration of immigrants in Catalan schools}

Twenty years ago immigration started to be significant, and it escalated after 2000. For this period, the Spanish Parliament has passed three Acts on the Foreign Status (one in 1985, two in 2000), constraining the status of 'regular foreigners' to relatives of nationals and workers listed in the yearly official stock. The routine of ordinary policymaking has also made autonomous communities and municipalities responsible for integration (Garreta, 2007).

Many newcomers have since faced strong difficulties to attain this condition, but all are

2 In 2006, the bulk of foreign- born students enrolled in primary education came from Southern America 
entitled to some rights, and most of them get low-paid jobs. In fact, only a fraction of 'foreigners' benefited from easier requirements during some special periods of 'regularisation' (mostly, in 1991 and 2004); however, social rights such as education and health have been guaranteed on a universal basis. In the labour market most immigrants earn their living as agricultural labourers, industrial workers, shop assistants, cleaners or 'family workers' (hired to take care of the elderly), whereas an important group have started small firms (Cavalcanti, 2007). Needless to say, their former social background, as well as both gender and ethnic relations, have patterned this particular outcome in terms of social stratification.

Unsurprisingly, appropriate strategies for educational integration have become important bones of contention. First, from the very beginning education has been the main social space where all the population actually met, but not in the same schools. By 2000 a high percentage of compulsory education students $(40 \%)$ were enrolled in private-dependent schools ${ }^{3}$. The bigger share $(25 \%)$ of these educational institutions were denominational, mostly Catholic, but a number of them were laic (15\%). Almost half of students attended state schools -run by the Catalan government-, and finally, a small proportion were enrolled in private independent schools. Noticeably, at that time many more 'foreigners' were enrolled in state-run $(3.5 \%)$ than in private-dependent schools $(0.8 \%)$. Contemporary professional and political debates focused on the segregation of these new, heterogeneous, ethnic minorities who were only visible through an indirect proxy of ethnic relations such as their 'foreign' condition (Carbonell, 2000; Palaudàrias, 2002).

(6\%), mostly Ecuador and Peru, and Northern Africa (4\%), mostly Morocco.

3 Private-dependent schools are run by foundations or co-operatives; they receive state funds in the terms established by a contract with the government, and are allowed to charge some fees (whose average share 
Second, most policy-makers, experts, unions and teachers assumed to prioritise intercultural (i.e. emphasizing interaction) instead of multicultural (i.e. adding references to new groups) education. Basically, whilst multiculturalism was widely blamed for inducing cultural relativism and creating ghetto schools, intercultural pedagogy was expected to stress dialogue, reciprocal relations and broad understandings (Hannoun, 1992).

Both segregation and curriculum adaptation triggered a wide array of ideological interpretations and guidelines with contradictory goals. Actually, the whole educational community searched for new professional tools tailored for students who were not always fluent in Spanish (never in Catalan) and lived in very different cultural frameworks. However, from a longer-term stance it is plausible to understand that those ideas were inspired on a 'unitary approach' to social inequalities, since that conventional wisdom asked specialists in compensatory education and curriculum adaptation to deal with a 'static and uniform social category' (Hancock, 2007: 64) concentrated in a few public, state-run schools.

But an expanding body of research unveiled important shortcomings, overall, the inherent difficulty to profile two exclusive types of multi- and inter- cultural pedagogy (Alegre, 2005). Besides, these pedagogic tools lacked operative solutions to emerging questions: e.g. homogeneous intake areas, religious misunderstandings, ethnically biased peer grouping, fragmenting ordinary and extra-ordinary curriculum designs, dissonant educational expectations and episodic conflicts. Ethnographies saw a complex 
web of social divisions -like class, gender and age- that underlay these questions (Bonal et al, 2004; Alegre, 2005). On the other hand, this research also found out the wellknown patterns of 'racialisation' which are so common in many Western countries (Delgado, 1998; Carrasco, 2003), even more, it observed powerful expressions of biological racism (Fullana et al, 2003).

So far, these qualifications draw on the 'multiple approach' to the education of the new Other Catalans, which highlights several categories at both the individual and the institutional level (Hancock, 2007: 64). From an empirical stance, the initial, 'unitary' diagnosis is not completely rejected, but many new sociological empirical questions and practical dilemmas emerge. Besides the distribution of students between institutional sectors, and the alleged benefits of intercultural pedagogy, now it is necessary to understand the local situation of any school, the intricacies of religious pluralism, the diversity of peer groups, the potential perverse effects of pedagogic innovation, the previous school experiences of students and a variety of conflicts and negotiations. From a practical stance, many professionals aim to implement inter-/multi-cultural strategies taking account of 'multiple' social categories at the classroom, the school and the local levels.

\section{An 'intersectional approach' to the integration of immigrant students in Catalan schools}

It is our view that an 'intersectional approach' would be really helpful to tackle all these issues, and additionally, we can advance in this direction by exploring school segregation at a local geographical scale. Thus, we will try to point out the main 
strengths of this approach in the following paragraphs, and to underpin our expectations with a more detailed analysis in the next sections. In a general sense, this perspective contributes to a sociological understanding of inequalities that is aware of power relations in diverse fields of activity where the intricate connections between human agency and social structure are enacted.

Basically, any analysis of social inequality is 'intersectional' inasmuch as it captures the crossroads of more than one social division (Hancock, 2007: 64). Class, gender, ethnicity and disability are common factors and markers of these divisions which we cannot study in an independent way. But it would not be plausible to conflate all these sets of social relations in a simple grid of rows and columns; on the contrary, each one keeps some particular ontological features in all possible intersections.

\begin{abstract}
At the same time, it is important to remember that the ontological basis of each of these divisions is autonomous, and each prioritizes different spheres of social relations (...) For example, class divisions are grounded in relation to the economic processes of production and consumption; gender should be understood not as a 'real' difference between men and women, but as a mode of discourse that relates to groups of subjects whose social roles are defined by their sexual/ biological difference while sexuality is yet another related discourse, relating to constructions of the body, sexual pleasure and sexual intercourse. Ethnic and racial divisions relate to discourses of collectivities constructed around exclusionary/ inclusionary boundaries (...) that can be constructed as permeable and mutable to different extents and that divide people into the 'us' and 'then'. (...) 'Ability' or, rather, 'disability' involves even vaguer and more heterogeneous discourses than those relating to ethnicity, as people can be 'disabled' in so many ways" (YuvalDavis, 2007: 201)
\end{abstract}

Intersectional analyses explore these sets of social relations in different institutional domains, for instance, the economy, the polity, the family and others. These sets of relations are defined by causal interdependence between agents and the positions they occupy, and the domains frame agents' expectations. No causal hierarchy is hypothesized between these distinct social processes (Walby, 2007).

When analysing the school segregation of 'foreign students' in Catalonia between 2001 
and 2006, we are looking at the intersection of class and ethnic divisions. The class location of immigrants is a traditional topic of specialised research (Cavalvanti, 2007); and the ethnic division relates to the construction of an exclusionary boundary based in the 'citizen/ foreigner' status and the social composition of schools (Carrasco, 2003).

The 'intersectional approach' also distinguishes identity and social position (Hancock, 2007; Yuval-Davies, 2007). Such a conceptual qualification reminds of the general concepts of social sciences, and avoids most current overstatements about the behaviour of minority students and families. In essence, the available datasets provide a proxy of minority and majority students, whose appropriate interpretation must take account of these two social divisions in the educational domain.

Therefore, in this domain social agents deploy their strategies in many occasions, such as choosing a school for their offspring or managing the enrolment period. These strategies are likely to mould the local maps of 'foreign students' by combining class and ethnic relations. At least, previous research suggests that they play two roles:

a) Middle-class families forecast the advantages and inconveniences of their school choices in explicit and careful ways, whereas most working-class families follow widespread customs in their neighbourhood when enrolling children in the nearest school (Ball, 2003; Rambla, 2006). Similarly, most minority parents would rather send their children to close schools on routine and practical grounds (Zanten, 2003). Segregation is a likely outcome if all schools do not share a similar social mix, because upper-class parents often fly away from schools where they fear that 'too many' minority students may damage average learning in a heterogeneous classroom group. 
b) By the 1985 Act on the Right of Education, and more recently, the 2005 Organic Act on Education, all state-run and private-dependent schools are required to provide free education to any student who prefers them. These legal norms notwithstanding, many use informal deterrence to prevent unwanted students from enrolling. For example, some schools overcharge families for school kits and Parents Association fees. Some private-dependent schools also exaggerate Catholic requirements and charge fees to fund their own non-profit organisation (Villarroya, 2002). Eventually, in Catalonia this informal selection closes the gates of some state-run schools and most privatedependent schools to minority students (Palaudàrias, 2002).

Finally, let us point out that geographic scales are at stake. Many authors have observed qualitative changes when some social phenomena move from one geographical scale to another: for example, besides national cleavages, local collective conflicts are particularly significant in post-industrial societies (Harvey, 2000); similarly, global actors set the educational agenda, and governments make decisions within this framework, but localities and municipalities receive heterogeneous effects (Dale, 2005).

If classroom groups, schools and localities are conceptualised as different geographical scales where social domains are embedded, it appears that the aforementioned works have so far overlooked the local dimension in Catalonia. For this reason, in the following sections we estimate the effective trends of school segregation, not only by comparing private and state-run schools but also by classifying middle-sized localities. Thus we inquire whether the local school system makes a difference after controlling for obvious factors related to size. 


\section{Local school maps}

The free choice policies that many Anglo-Saxon countries and Sweden have adopted are in contrast to the rule in Continental Europe. Here, students are allocated to public, state-run schools in administrative ways, while choice is restricted to private-dependent schools either guided by religious, pedagogic or ideological principles (Glenn, 1989). However, recent research findings also report strategic choice in these countries, where class and ethnic biases increasingly drive parental preferences (Dronkers, 1995; Broccolichi and Zanten, 2000).

In Spain families are entitled to choose a school according to their values (by the 1978 Constitution), and private- dependent schools are required to provide free education and teach the common curriculum to all students that choose them (by the 1985 Act on the Right to Education, with some stronger controls established by the 2005 Act on Education). Besides a margin for further legislative development, the education department of the Catalan autonomous government is in charge of budgeting, human resources and inspectorate. From 1980 until 2003, Conservative governments openly favoured private schools, whose enrolment rate is higher in Catalonia (40\%) than it is in Spain as a whole (30\%). Since 2003, plural- Left governments have strengthened surveillance of any irregular privilege by setting local offices that monitor the enrolment process.

After the late nineties, concern with segregation has extended, and local authorities ask for playing an official role in 'local school maps'. Roughly speaking, this expression 
means that enrolment policies distribute students into schools which are formally committed to an educational area. Even though in 2000 the Two SEN Seats measure against segregation was implemented, so that all state-run and private-dependent schools must reserve two places for students with Special Education Needs (SEN) in each classroom, nowadays the school rate of 'foreign students' still records a high variation from $5 \%$ to $40 \%$. The reach of private-dependent schools also makes a difference: normally, all neighbourhoods have at least one state-run school, and privatedependent schools are located in downtown districts; however, in some cases peripheral neighbourhoods also have their private-dependent school(s). Even more, in some localities all state-run and private-dependent schools are formally expected to admit students from their educational area. In a few cities, several types of schools are included in the same educational areas, whereas in many others private-dependent schools are exempt from any requirement related to proximity.

\section{Trends of school segregation: data and main findings}

Segregation is at stake when the distribution of two social groups (e.g., social classes, SEN students, ethnic majorities or minorities) either is uneven between a set of social units (e.g., schools, districts, localities) or isolates a group in a unit so that its exposure to mainstream social interaction is constrained. Thus, (un)evenness depends on the distance between the actual distribution and a counter-factual, unbiased distribution, whereas isolation/exposure consists of the probability of two social groups being in contact within the same social units (Massey and Danton, 1988).

Among the various indices of unevenness, we have chosen those which are particularly 
sensitive to the segregation curve (Allen and Vignoles, 2007). Thus, the Dissimilarity Index (D) measures the proportion of minority children who should move to another school in order to get an even distribution (Duncan and Duncan, 1955), and the Hutchens Index $(\mathrm{H})$ is perfectly decomposable in social sub-units such as districts or institutional sectors (Hutchens, 2004). Conversely, the Isolation Index (I) and its correction (IC) capture the proportion of minority students in the same school for an averaged student minority. Although I is much easier to interpret, IC adds significant information about within- district isolation (Noden, 2000).

Census data report the proportion of 'foreign students' in Catalan primary schools, dramatically increasing from 2001 (3\%) to 2006 (12\%), which is the best available estimate of ethnic distribution, and an indirect proxy of some lower-class positions. Our sample includes the 158 largest cities (except for Barcelona) and 1524 schools (62\% state-run, 38\% private-dependent). In most cases the population amounts to more than 5.000 inhabitants, although exceptionally a few small regional capitals have been taken into account despite their lower population. As a rule, this sample will permit us to observe both national and local patterns of segregation, because it has excluded the biggest city and the smallest villages and towns (around 700 localities).

Two graphs and one table summarize the main findings. Graph 1 plots a decreasing trend of unevenness according to Hutchens, with an important reduction between 2001 and 2004, and a steady trend later on. Coherently, the Dissimilarity Index shitted from $55 \%$ in 2001 to $46 \%$ in 2006 , that is, at the end of the period a smaller number of 'foreign students' should move to a different school in order to get an even distribution. Two comments must be highlighted: on the one hand, the most significant reduction and 
the arrival of more immigrants were simultaneous, and on the other hand, the Two SEN Seats policy probably contributed to counteract unevenness before the proportion of 'foreigners' augmented.

For all these years, within-district segregation has been much more intense than between-district segregation. Thus, it is not reasonable to attribute the uneven biases to the ongoing urban sprawl; on the contrary, many 'foreign students' are enrolled in certain schools at the same time as their presence is much lower in other, neighbouring schools.

$<$ Graph 1 around here>

Graph 2 detects rampant isolation from 2001 to 2006 in Catalonia. The raw isolation index (I) depicts a curve moving upwards, and the corrected isolation index (IC) replicates the same net outcome controlling for the total amount of newcomers. Noticeably, more and more 'foreign students' have become concentrated in a few schools where they can hardly meet autochthonous mates. In 2006 they were $12 \%$ of students, but most of them attended schools with a $25 \%$ of students born in other countries.

\section{$<$ Graph 2 around here>}

Finally, Table 1 distinguishes a type of local school segregation with dominant unevenness between state-run schools, and another type with dominant unevenness between the state-run and the private-dependent institutional school sectors. The table is 
the outcome of a factor analysis taking account of the selected segregation indices and the main local, social features (such as population, share of enrolment in privatedependent schools and percentage of 'foreign students'). Actually, previous qualitative research on the local governance of choice and segregation has already unveiled some differences, but so far their general influence could not be estimated with a few case studies (Gonzalez and Valiente, 2006).

Factor 1 and Factor 2 altogether account of more than $35 \%$ of overall variance. In brief, isolation, unevenness between state-run schools and a larger population are the main contributors to Factor 1, whilst Factor 2 is tightly associated with (higher) betweensectors unevenness and (lower) enrolment in private- dependent schools in small towns. These statistical regularities portray two types of local school segregation.

$<$ Table 1 around here>

First, in larger cities 'foreign students' are not distributed in an even way between staterun schools, and face a much more isolated environment. These are the main provincial capitals as well as important suburbs in the metropolitan area of Barcelona. They score different proportions of enrolment in private-dependent schools, and are not the extreme examples of a polarised social composition between institutional sectors. In essence, it seems that only a few local state-run schools cater for the incoming school-age population.

Second, in a variety of towns state-run and private-dependent schools have specialised in different intakes. Most of these localities are ranked along an inverse relationship: the 
lower their rate of 'foreign students', the higher their enrolment in private-dependent schools, and the more uneven their distribution between state-run and private-dependent schools. Here, incoming students enrol in local state-run schools, whereas they seldom go to the neighbouring private-dependent schools.

\section{Intersecting divisions in 'local school maps'}

Our general hypothesis relies on three pieces of evidence. In a nutshell, it states that school- choice exclusionary strategies and informal school- selection practices altogether segregate many 'foreign students', most of them grown up in working-class environments, in a few state-run schools in middle-sized Catalan localities. Class- and ethnic- biased inter-group comparison leads the upper families to fly away from an allegedly dangerous social mix. Some state- run and many private-dependent schools raise informal barriers to prevent undesired students to enrol. These families and these schools are able to establish very influential alliances to widen channels of class and ethnic flight, whatever the local institutional environment is.

Basically, the available evidence underpins these observations with some correlations between the Two SEN Seats policy and unevenness, as well as with statistical proof of a fragmenting state-run sector in many cities, and diverging composition of state-run and private-dependent schools in many others.

First, as the Two SEN Seats policy aimed, between 2001 and 2006 many immigrants reduced unevenness by enrolling their offspring in a broader variety of schools. In the first years, low numbers of minority students were concentrated in a few schools in each 
village, town or city, but five years later their share had increased a little bit in many more schools. Therefore, the private-dependent sector could exhibit a formal commitment inasmuch as it reserved some places for students with special educational needs (SEN). Compared to the nineties, the incoming population was much more numerous, and the two school sectors were much more involved in their education.

However, isolation increased; that is to say, in those few schools where they were more numerous, the portion of 'foreign students' amounted for more and more above-average percentages. This entailed lower probability of interaction, an intermittent exposure to engage in relationship with the indigenous youth, and a harmful frustration of the pedagogic and official expectations attached to intercultural ideals. Further research would be sensible to ask whether isolation constrains the social trajectories of these minority students and conditions the changing images of their identities.

Second, the state-run school sector has been fragmented in many middle-sized towns as well as first- and second-order capitals that compose the urban network of Catalonia. In these localities, a high proportion of 'foreign students' concentrates in a few state-run schools. Despite important differences, some researches conducted in France suggest that the main cause of this pattern may be the failure of educational governance due to strategic parental choices and broader urban changes. In France, policy contradictions cause school segregation to aggravate even though most schools are run by the state and must comply with very strict enrolment rules attached to intake areas. Over all, these areas have not changed for fifty years despite urban polarisation; nowadays, neither the Ministry nor the provincial Rectorats and the municipalities are able to counteract the rapidly moving territorial divides (Felouzis et al, 2005). 
In Catalonia these contradictions are even stronger because of informal arrangements. Besides, in most towns certain state-run schools have constructed a high local esteem on the grounds of their institutional origin (they were former private schools teaching in Catalan during the dictatorship), their pedagogic innovation (e.g. participating in research programmes, 'greeening' some subjects and activities) and their efficient Parents Association (that organises sports activities and summer camps). Like their private-dependent 'competitors', many of them also prevent unwanted families from enrolling by delivering partial information on academic standards or expected fees, and attract the preferred families by tolerating short-term registration in the neighbourhood (renting a flat, using grandparents' address) and redrawing their opaque intake areas (Gonzalez and Valiente, 2006).

Third, in a variety of towns the social composition of state-run and private-dependent schools has been polarised. Generally speaking, this circumstance may be attributed to effective lobbying of interest groups representing private-dependent schools (Bonal, 2000).

Twenty years ago massive mobilisation opposed supporters and detractors of the Act on the Right to Education. The former party vindicated public surveillance of private schools with state funding; the latter claimed for educational freedom against any condition imposed in exchange for public subsidies (e.g. co-educational schooling, commitment with educational areas, and participative school councils).

The bulk of supporters were teacher unions, Progressive pedagogic associations and 
left-wing political parties. Afterwards, these groups have repeatedly used mobilisation, with some significant internal cleavages. Thus, in the early nineties, they campaigned for an act guaranteeing sufficient funding to implement the 1990 comprehensive Education Reform Act, but it was not either presented to the Parliament. They also opposed the 2002 Act on Educational Quality in a similar way (later on, it was abolished by the incumbent Socialist Party), and an important part have marched against recent reforms (e.g. the 2005 Organic Act on Education).

As to detractors, they were (and are) religious and laic associations representing private schools who learnt to compromise with governmental policy in exchange for ad-hoc, local advantage (Bonal, 2000). Thus, in the late eighties they were officially allowed to charge a fee, and implicitly, to select their students in personal interviews. Later on, they could implement pilot experimental, comprehensive programmes which were simultaneously delayed in neighbouring state-run schools due to budget shortcomings. Recently, the extension of public subsidies to their infant education courses has not only been very helpful for their financial situation, but also reinforced their position compared to smaller state schools where children arrive from several nursery schools. If a bigger school can provide subsidised courses for one- and two-year olds, and avails of tolerated informal margins to select its intake since the age of three (i.e. the first official course), it can also promise a place in a 'selected' primary programme and a smooth transition to compulsory secondary education (Benito and González, 2007).

This interest group operates at all the levels of political decision by pressuring mayors, mobilising middle-class voters, lobbying in the local branches of education departments, sitting in local, regional and state school councils, and spreading opinion 
on governmental decisions at the autonomous and central levels. Although its core associations are some federations of Catholic school-owners and Catholic parents, sometimes their demonstrations have been supported by wider, popular, Catholic religious demonstrations (Griera, 2007).

\section{Conclusion}

Research makes small steps that sometimes raise new issues. We hope we deepened our understanding of the new Other Catalans' position in the school system by arguing for an intersectional approach to education and immigration issues. In our view, it inspires empirical questions whose quantitative results elucidate some keys of local disparities.

An intersectional approach defines sets of social relations (class, gender, ethnicity and so forth) and distinguishes domains of action. By drawing on these concepts, we try to explain the current trends in school segregation. Basically, the general policy reserving two seats for SEN students in all schools has curbed unevenness; but furthermore, parental exclusionary strategies and underground selective admission seem to have isolated 'foreign', normally working-class, students in a few state-run schools. Contrasted practices of state-run and private-dependent schools have played an important role in this story, but other processes also make a difference within the staterun sector in many localities. Therefore, the local scale should not be neglected any longer.

The heritage of Catalan social research also posits fresh challenges to our conclusion. If we are right, the conventional distinction of intercultural and multicultural pedagogy is 
insufficient, as well as the compared proportions of 'foreigners' in school sectors only portray a partial account that disguises deeper questions. However, the analysis is not complete until we find out how are middle-class families distributed between schools, how do different 'foreigners' see themselves and choose their children's school, how do gender relations impinge on these combinations of class and ethnicity (if they prove to do) and many other questions. In short, intersectional insights and available ethnographies (driven by a 'multiple- approach' perspective) should be combined in order to make the next step.

\section{References}

Alegre, M.A. 2005. Geografies adolescents a secundària [Teenager 'geographies' in secondary schools]. Cerdanyola: Ph Dissertation (UAB).

Allen, R. and Vignoles, A. 2007. What should an index of school segregation measure?. Oxford Review of Education 33, no 5: 643 - 668.

Ball, S. 2003. Class strategies and the education market : the middle classes and social advantage. London: Routledge Falmer.

Benito R, González, Isaac,. 2007. Processos de segregació escolar a Catalunya. [Segregation processes in Catalonia]. Barcelona: Fundació Jaume Bofill.

Bonal, X. 2000. Interest Groups and the State in Contemporary Spanish Education Policy. Journal of Education Policy 15, no: 201-216.

Bonal, X. et al. 2004. Apropiacions escolars [Cultural appropriations at school]. Barcelona: Octaedro.

Broccolichi, S. and Zanten, A. V. 2000. School competition and pupil flight in the urban periphery. Journal of Education Policy 15, no 1: 51-60.

Candel, F. 1964. Els altres catalans [The other Catalans]. Barcelona: Edicions 62.

Candel, F. and J. M. Cuenca, J.M. 2001. Els altres catalans del segle XXI [The Other Catalans from the XXI century]. Barcelona: Planeta.

Carbonell, F. (coord) 2000. Educació i immigració. Els reptes educatius de la diversitat cultural $i$ l'exclusió social [Education and immigration. Educational challenges emerging from cultural diversity and social exclusión]. Barcelona: Editorial Mediterrània. 
Carrasco, C. 2003. La escolarización de los hijos e hijas de inmigrantes y de minorías culturales [Schooling patterns of the immigrants' and ethnic minorities' offspring]. Revista de Educación 330: 99-136.

Cavalcanti, L. 2007. El papel del protagonismo empresarial latinoamericano en la (re)construcción social de la categoría «inmigrante» en España [The role of Latin American entrepreneurs in the reconstruction of the 'immigrant' category in Spain]. Papers. Revista de Sociologia85: -191.

Dale, R. 2005. Globalisation, knowledge economy and comparative education. Comparative Education, no 2: 117-149.

Delgado, M. 1998. Integració $i$ diversitat [Integration and diversity] Barcelona: Empúries.

Dronkers, J. 1995. The existence of parental choice in Netherlands. Educational policy 9, no. 3: 227-243.

Duncan, O. D. and Duncan, B. 1955. A Methodological Analysis of Segregation Indexes. American Sociological Review 20: 210-17.

Fullana, J. X. Besalú, X. and M. Vila. 2003. Alumnes d'origen africà a l'escola [Pupils from an African origin at school]. Girona: CCG.

Garreta, J. 2007. Continuidad y cambios en la gestión de la inmigración [Continuity and change in immigration policy]. Papers. Revista de Sociologia 85: 71-93.

Glenn, C. 1989. Choice of Schools in Six Nations. Washington: Government printing office.

González, I. and Valiente, O 2006. Les Oficines Municipals d'Escolarització i el paper de l'Administració local en les polítiques d'accés escolar. [Local Schooling Offices and the role of local administration in education policy] In: X. Bonal (Coord.) Anuari de l'educació, [Yearbook of education] Barcelona: Fundació Jaume Bofill.

Griera, M. 2007. The Education Battle: the Role of the Catholic Charge in the Spanish Education System. In: Gerald Grace and Joseph O'Keefe (eds). International Handbook of Catholic Education. Dordrecth (NL): Springer pp.291-310

Hancock A-M. 2007. When Mutiplication Doesn't Equal Quick Addition: Examining Intersectionality as a Research Paradigm. Perspectives on Politics5: 63-79.

Hannoun, H. 1992. Els ghettos de l'escola: per una educació intercultural[School ghettos: for intercultural education] Vic: Eumo.

Harvey, D. 2000. Spaces of Hope. Berkeley: Univ. of California Press.

Hutchens, R. 2004. One Measure of Segregation. International Economic Review 45, no 2: 555- 70 . 
Massey, D. S.; Denton, N. A. 1988. The dimensions of residential segregation. Social Forces 67: 281-315.

Noden, P. 2000. Rediscovering the Impact of Marketisation: dimensions of social segregation in England's secondary schools, 1994-1999. British Journal of Sociology of Education 21, no. 3: 371-390.

Palaudàrias, J.M. 2002. Escola i immigració estrangera a Catalunya: la integració escolar [School and immigration in Catalonia: school integration]. Papers. Revista de Sociologia, 66: 199-213.

Rambla, X. 2006. L'alchimie des aspirations educatives: la confiance dans les mérites scolaires en Espagne [Alchemy of educational aspirations: trust in school merits in Spain]. Regards sociologiques 31: 17-34.

Villarroya, A. 2002. A look at school choice in Spain. Mediterranean Journal of Educational Studies 7, no 2: 21-36.

Walby S. 2007. Complexity Theory, Systems Theory, and Multiple Intersecting Social Inequalities. Philosophy of the Social Sciences 37: 449-70

Woolard, K. 1989. Double Talk. Bilingualism and the Polities of Ethnicity in Catalonia. Stanford: Stanford University Press.

Yuval-Davis N. 2006. Intersectionality and Feminist Politics. European Journal of Women's Studies 13: 193-209.

Zanten, A. v. 2003. Middle-class Parents and Social Mix in French Urban Schools: reproduction and transformation of class relations in education. International Studies in Sociology of Education, , no 2: 107-125. 


\section{The new Other Catalans at school: decreasing unevenness but increasing isolation}

Graph 1: Uneven distributions of 'foreign students' at school from 2001 to 2006.

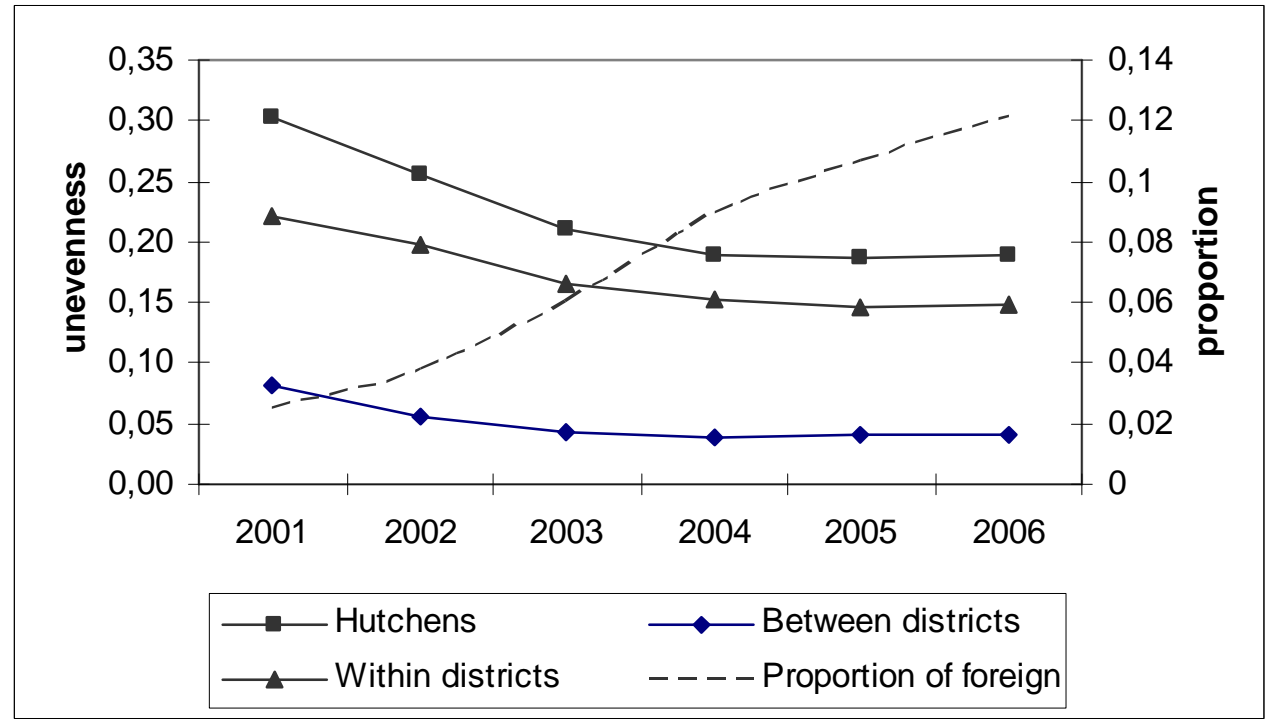


Graph 2: Isolation of 'foreign students' at school from 2001 to 2006.

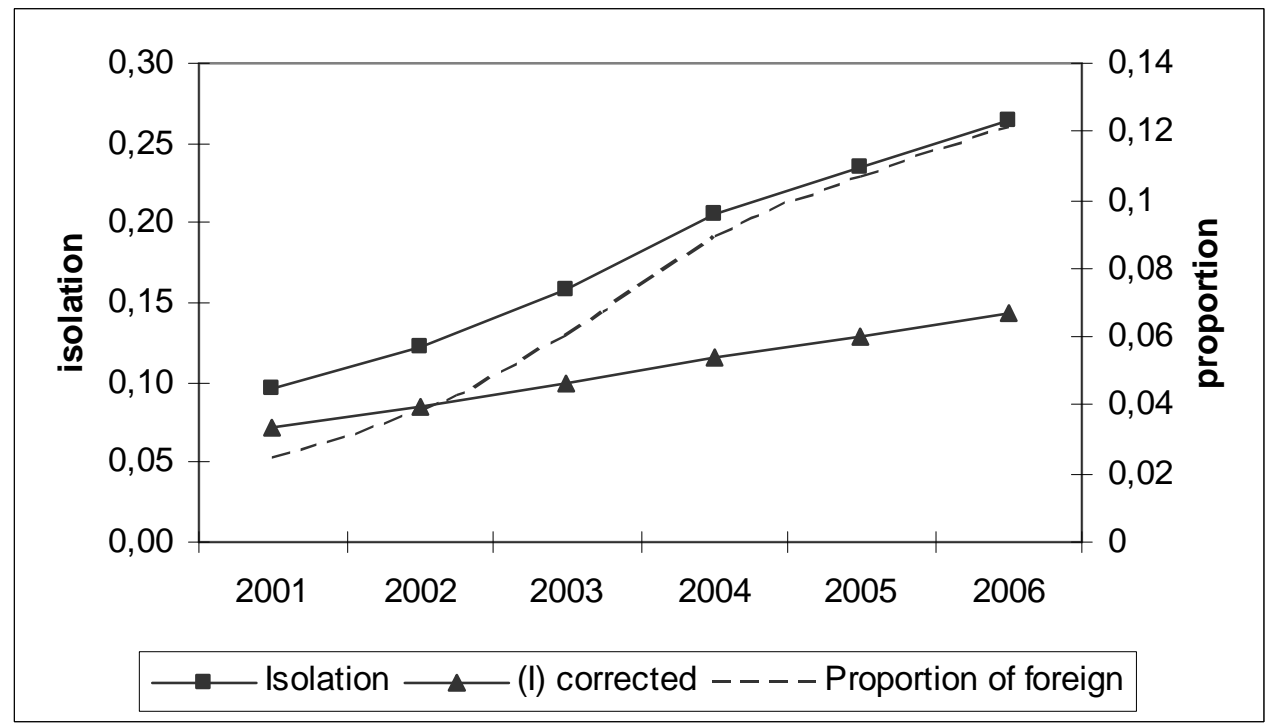


Table 1: Social structure and segregation indices at the local level.

\begin{tabular}{|l|r|r|}
\hline & Factor 1 & Factor 2 \\
\hline Local social structure & & \\
\hline Population & 0,782 & 0,093 \\
\hline Proportion of students in private-dependent schools & 0,258 & 0,621 \\
\hline Proportion of 'foreign students' enrolled in local schools & 0,297 & $-0,544$ \\
\hline Local school segregation & & \\
\hline Unevenness between public schools & 0,746 & 0,080 \\
\hline Hutchens unevenness index & 0,622 & 0,703 \\
\hline Dissimilarity (unevenness) index & 0,556 & 0,762 \\
\hline Unevenness between public and private-dependent school sectors & 0,210 & 0,867 \\
\hline Isolation (I corrected) & 0,928 & 0,167 \\
\hline
\end{tabular}

